\title{
Psychological Capital as Predictor of Organizational Commitment and Organizational Citizenship Behavior
}

\author{
Prof. Anu Singh Lather ${ }^{1}$, Ms. Simran Kaur ${ }^{2}$
}

\section{ABSTRACT}

This paper examined psychological capital in two types of organizations: public and private schools. This study explained how psychological capital effects organizational commitment and organizational citizenship behavior in public and private schools. The sample includes 150 employees, 75 each from two types of schools. Various dimensions of Psychological Capital were measured by scale developed by Luthan, Youssef \& Avolio. Organizational Commitment was measured by Allen \& Meyer's scale and Organizational Citizenship Behavior by a scale developed by Podsakoff. The result obtained from Pearson correlation and stepwise multiple regressions and it showed that all the dimensions of psychological capital were significantly different in the both the kind of schools. Regression analyses showed that psychological capital as a whole can predict organizational commitment and organizational citizenship behavior in both kinds of schools. The theoretical framework proposed in the paper on Psychological Capital would help the researchers and management people to understand the impact of Psychological Capital on organizational commitment and organizational citizenship behavior. It also supports the view of previous researchers that Psychological Capital is a significant positive organizational behavior variable, as it is capable of performance improvement and is open to development.

Keywords: Psychological Capital, Organizational commitment, Organizational Citizenship Behavior, Public and Private schools

Constructive organizational behavior and psychological capital are very significant advances and their origin can be outlined to positive psychology movement in Psychology. Human capital was conceptualized by Fitzenz (2000). According to him, Human Capital comprises of four subcategories: Psychological capital, Intellectual capital, Emotional capital, and Social capital, collectively known as "PIES". The concept of Psychological capital is anticipated as one of vital dimension of human capital which can benefit to solve the human issues in the organizations.

\footnotetext{
${ }^{1}$ Director- International Affairs, Guru Gobind Singh Indraprastha University, Dwarka, India ${ }^{2}$ Research Scholar, Guru Gobind Singh Indraprastha University, Dwarka, India (c) 2015 I A Lather, S Kaur; licensee IJIP. This is an Open Access Research distributed under the terms of the Creative Commons Attribution License (http://creativecommons.org/licenses/by/2.0), which permits unrestricted use, distribution, and reproduction in any Medium, provided the original work is properly cited.
} 


\section{Psychological Capital as Predictor of Organizational Commitment and Organizational Citizenship Behavior}

Psychological capital can be described as an individual's positive psychological state of development, which consists of four dimensions: self-efficacy/confidence, hope, optimism, and resiliency. The rise of the positive psychology movement resulted in increase in awareness on the significance that positive psychological strengths and dimensions can have on human working. Luthans (2002a, 2002b) and Cameroon et al. (2003) made the efforts to further expand positive psychology movement to the work areas which concluded in the publication of an edited volume on Positive Organization Behavior (Nelson \& Cooper, 2007).

As stated above, the psychological capital is a composite construct consisting of four dimensions - confidence (efficacy), hope, optimism and resilience (Luthan, Luthans, \& Luthans, 2004), description of these dimensions are presented below:

(1) Confidence/ Self-efficacy: It refers to people's convictions about their own capacity for successfully executing a course of action that leads to a desired outcome (Bandura,1997).

(2) Self-confidence: people having high level of self-confidence, select challenging job and attempt to successfully accomplish their objectives. Confident people achieve goals and continue even in presence of obstacles. Bandura (2000) has noted that self-efficacy plays a critical role in important human performance determinants such as goals, aspirations, and the perceived opportunities of a given project. Stajkovic and Luthans(1998) conducted a meta-analysis of 114studies and 21,616 subjects and found a positive and highly significant .38 weighted average correlation between self-efficacy and performance outcomes.

(3) Hope: Snyder (2000) explains that hope is a multidimensional concept which consists of both a person's willpower to make and maintain efforts toward goals and that individual's ability to discern alternative courses of action to attain those goals. It is a motivational state that has three elements - goal, action and strategies. Hopeful people have the need to achieve goals and have the capability to develop various strategies toward goal accomplishment.

(4) Optimism: Luthans and Youssef (2004)defines optimism as" explanatory style that attributes positive events to internal, permanent and pervasive causes and negative events to external, temporary and situation specific one's”. Optimistic people take credit for good things that happen to boost morale and distance themselves from bad things that happen. Optimism has been associated with the improvement of performance (Martin, Sarrzon, Peterson \&Famose, 2003).

(5) Resilience: It refers to having the capacity to bounce back from adversity, failure or even seeming overwhelming positive changes such as increased responsibility. Resilient 


\section{Psychological Capital as Predictor of Organizational Commitment and Organizational Citizenship Behavior}

individuals possess a 'staunch acceptance of reality, a deep belief, often buttressed by strongly held values, that life is meaningful and an uncanny ability to improvise' (Coutu, 2002). Recent analysis by organizational scholars suggests that resilient people can thrive and grow through setbacks and difficulties.

Each of the above mentioned elements of psychological capital has been explored to some extent within the organizational literature (Petersons \& Luthans, 2003; Schepman \& Richmond, 2003). Luthans and colleagues have demonstrated a clear linkage between psychological strengths and positive workplace outcomes in a variety of contexts and industries. For example, Peterson and Luthans (2003) have noted that leader's hope significantly relates to business unit financial performance (.35), employee satisfaction(.41), and employee retention (.37), while another study focused on entrepreneurs indicated a significant positive link (.57)between the business founder's reported hope levels and his/her satisfaction with business ownership (Jensen \& Luthans, 2002). A study of Chinese manufacturing employees (Luthans et al., 2004) also indicates a significant positive link between work performance and the workers' levels of resiliency (.36) and hope (.25). Seligman (1990) found a highly significant linkage between measured optimism and performance in the life insurance industry.

The research so far suggests that psychological capital is negatively related to employee absenteeism, employee cynicism and intentions to quit, and positively related to job satisfaction, commitment, organizational citizenship behaviors, employee performance and leadership effectiveness (Luthans, Avolio, Walumbwa, \& Li, 2004). These results have also been successfully replicated in China (Zhong, 2007). However, we couldn't find studies on it in the Indian context.

Organizational commitment can be defined as power of an individual's identification with and involvement in a particular organization (Curry, etal., 1986). As a psychological variable, commitment symbolizes employee's association with the organization and effects membership in the organization(Meyer \& Allen, 1991). It has three components: affective attachment to the organization (affective commitment),perceived cost associated with leaving the organization(continuance commitment), and obligation to remain with the organization (normative commitment).

Organizational Citizenship Behavior can be defined as those workplace behaviors which are not defined in formal organizational reward system but have an impact of effective working of an organization (Greenberg 2005; Organ 1988; Organ \& Konovesky 1989; Zellars, Tepper \& Duffy, 2002). Organ's definition of Organizational Citizenship Behavior includes three aspects: Organizational Citizenship Behavior is optional behaviors which not a part of formal organizational reward system; Organizational Citizenship Behavior is beyond the requirement of Job description; and Organizational Citizenship Behavior is positively linked with organizational effectiveness. These kinds of behaviors are not required by the job or in case of any negligence, 


\section{Psychological Capital as Predictor of Organizational Commitment and Organizational Citizenship Behavior}

there will be no punishment; they are mostly personally preferred (Padsokoff et al., 2000: 513). "Volunteer" means there is nothing required by a job, the act is done without any compulsory rule. Greenberg and Baron defined OCB as working beyond the requirements of a job. So it can be concluded that volunteerism is the basis of OCB (Özdevecioğlu, 2003: 118).Various dimensions of OCB are as follows:

\begin{tabular}{|c|c|c|c|}
\hline Dimensions & Description & $\begin{array}{l}\text { Business setting } \\
\text { Examples }\end{array}$ & $\begin{array}{l}\text { Academic setting } \\
\text { Examples }\end{array}$ \\
\hline Courtesy & $\begin{array}{l}\text { The thoughtful and } \\
\text { selfless behaviors } \\
\text { that prevent work- } \\
\text { related problems for } \\
\text { others. }\end{array}$ & $\begin{array}{l}\text { To inform your } \\
\text { supervisor in case of } \\
\text { delay for a meeting. }\end{array}$ & $\begin{array}{l}\text { To inform lecture when } \\
\text { unable to attend the class } \\
\text { (Student's perspective); } \\
\text { To inform team } \\
\text { leader/member when } \\
\text { unable to attend the } \\
\text { meeting (Lecturer's } \\
\text { perspective). }\end{array}$ \\
\hline Conscientiousness & $\begin{array}{l}\text { The tendency of } \\
\text { going the extra mile } \\
\text { then required in order } \\
\text { to be more } \\
\text { productive in } \\
\text { organizational setup. }\end{array}$ & $\begin{array}{l}\text { When required arrive } \\
\text { early and staying late } \\
\text { in the office. }\end{array}$ & $\begin{array}{l}\text { Submit assignments on } \\
\text { time } \\
\text { perspective) } \\
\text { Voluntarily doing more } \\
\text { work which is not } \\
\text { assigned (Lecturer's } \\
\text { perspective). }\end{array}$ \\
\hline Personal Support & $\begin{array}{l}\text { Voluntary } \\
\text { participation } \\
\text { in, and support of, } \\
\text { organizational } \\
\text { functions } \\
\text { of both a } \\
\text { Professional and } \\
\text { social nature for the } \\
\text { organization's best } \\
\text { interests. }\end{array}$ & $\begin{array}{ll}\text { Attend } & \text { optional } \\
\text { meetings, } & \text { training } \\
\text { sessions, etc. } & \end{array}$ & $\begin{array}{l}\text { Volunteer to help organize } \\
\text { or participate in college } \\
\text { activities such as campus } \\
\text { social events, speakers' } \\
\text { series, and philanthropic } \\
\text { activities. }\end{array}$ \\
\hline Sportsmanship & $\begin{array}{l}\text { A willingness to } \\
\text { endure the inevitable } \\
\text { problems and } \\
\text { compulsions that } \\
\text { exist in an } \\
\text { organization without } \\
\text { complaining, and } \\
\text { doing so with a } \\
\text { optimistic approach. }\end{array}$ & $\begin{array}{lr}\text { Abstain } & \text { from } \\
\text { complaining } & \text { about } \\
\text { overtime to complete } \\
\text { a project. }\end{array}$ & $\begin{array}{l}\text { Abstain from complaining } \\
\text { when team members do } \\
\text { not subsidize alike to team } \\
\text { projects. }\end{array}$ \\
\hline
\end{tabular}




\section{OBJECTIVES OF THE STUDY}

The following objectives were framed for the study:

(i) To determine the relationship between Psychological Capital and employees' commitment level

(ii) To determine the relationship between Psychological Capital and employees' level of organizational citizenship behavior

(iii) To determine if Psychological Capital can predict employees’ commitment level

(iv) To determine if Psychological Capital can predict employees' level of organizational citizenship behavior

\section{RESEARCH METHODOLOGY \\ Research Structure}

The research structure is drawn according to the research purposes. The research structure is presented in Figure1.

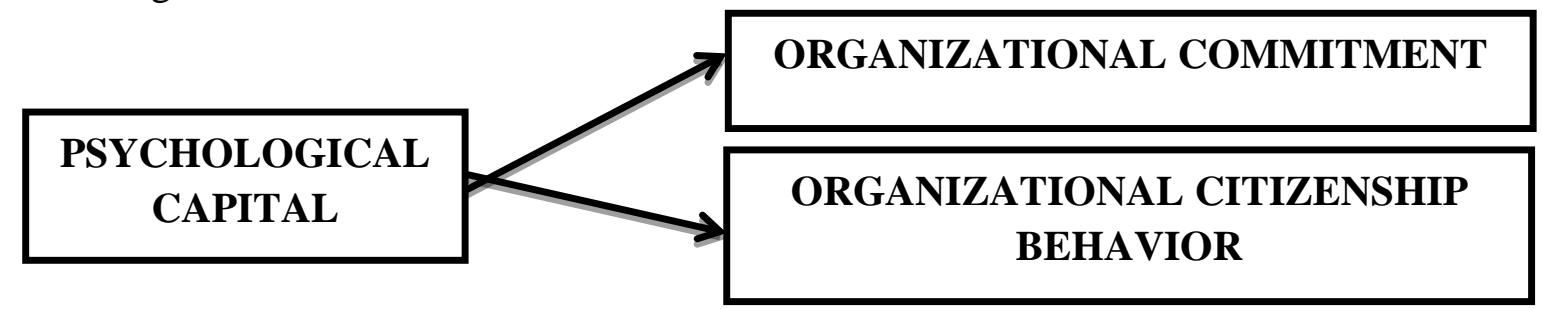

Figure 1: Research Structure

\section{HYPOTHESES}

Hypothesis 1: There is significant relationship between Psychological Capital and Organizational commitment

Hypothesis 2: There is significant relationship between Psychological Capital and Organizational Citizenship Behavior

Hypothesis 3: Psychological Capital can significantly predict the value of Organizational commitment.

Hypothesis 4: Psychological Capital can significantly predict the value of Organizational Citizenship Behavior.

\section{RESEARCH DESIGN}

The present study was Descriptive in nature. The proposed relationship was tested on a sample of 150 teachers of public and private school. The questionnaire was prepared in printed and online versions. The questionnaire contained a cover letter which provided brief instructions to the respondents and informed them of the purpose of the study. In almost all cases, questionnaires were personally distributed to the respondents and a brief verbal introduction about the purpose of the study was given. For the online version, emails were sent personally; it contained an introduction and hyperlinks to the two parts of the questionnaire. A total of 100 printed versions of the questionnaires were distributed; of these, 82 were returned by the respondents (82\% gross 


\section{Psychological Capital as Predictor of Organizational Commitment and Organizational Citizenship Behavior}

response rate). The online version of the questionnaire was e-mailed to 100 respondents; 68 responded to both parts (68\% net response rate). Thus the final sample available for analysis was that of 150 respondents

Tools

Scale 1: Psychological Capital (Luthan, Youssef \&Avolio, 2007b)

This scale analyzed four dimensions of Psychological Capital: Hope, Optimism, self-efficacy and resilience. The scale had 24 items i.e., 6 items of each dimension. This is a 7 point scale and scores on the scale varies from $1=$ strongly disagree to $7=$ strongly agree.

Scale 2: Organizational commitment (Allen \& Meyer, 1990)

It is a 24-item scale as a measure of organizational commitment having three factors of commitment(affective, normative, and continuance). This is a 7 point scale and scores on the scale varies from $1=$ strongly disagree to $7=$ strongly agree.

Scale 3: Organizational Citizenship Behavior scale (Podsakoff, 1990)

This scale consisted of four parts (total 19 items). The sub dimensions of scale are personal support, conscientious, courtesy and sportsmanship. The 5 of these 19 items are about the personal support, 4 for conscientious, 5 for courtesy and 5 for sportsmanship. It was developed by Podsakoff.

\section{Sample}

The present study was conducted on 150teachers of public and private schools, located in Delhi NCR region. Respondent's brief profile is mentioned below:

\begin{tabular}{|c|c|c|c|c|c|c|}
\hline \multirow{2}{*}{ S.No. } & \multirow{2}{*}{\multicolumn{2}{|c|}{ Background of Respondents }} & \multicolumn{2}{|c|}{ Public Schools } & \multicolumn{2}{|c|}{ Private Schools } \\
\hline & & & \multirow{2}{*}{$\begin{array}{l}\text { Number } \\
12\end{array}$} & \multirow{2}{*}{$\begin{array}{l}\text { Percentage } \\
8\end{array}$} & \multirow{2}{*}{$\begin{array}{l}\text { Number } \\
34\end{array}$} & \multirow{2}{*}{$\begin{array}{l}\text { Percentage } \\
23\end{array}$} \\
\hline 01 & Condor & Male & & & & \\
\hline 01 & Genuer & Female & 46 & 31 & 58 & 38 \\
\hline \multirow{4}{*}{02} & \multirow{4}{*}{ Age Group } & $20-25$ years & 4 & 3 & 7 & 5 \\
\hline & & $26-30$ years & 10 & 7 & 22 & 15 \\
\hline & & 31 - 35 years & 31 & 21 & 48 & 32 \\
\hline & & Above 35 years & 15 & 10 & 13 & 8 \\
\hline \multirow{4}{*}{03} & \multirow{4}{*}{$\begin{array}{l}\text { Tenure of } \\
\text { working }\end{array}$} & Less than 1 year & 5 & 3 & 7 & 4 \\
\hline & & $1-5$ years & 21 & 14 & 37 & 25 \\
\hline & & $6-10$ years & 18 & 12 & 19 & 13 \\
\hline & & More than 10 years & 27 & 18 & 16 & 11 \\
\hline
\end{tabular}

Table 1: Respondents Profile 


\section{FINDINGS AND DISCUSSION}

In statistics, Cronbach's (alpha) is a coefficient of internal consistency. It is commonly used as an estimate of the reliability of a psychometric test for a sample of examinees. Theoretically, alpha varies from zero to 1, since it is the ratio of two variances. Empirically, however, can take on any value less than or equal to 1 , including negative values, although only positive values make sense. Higher values of are more desirable.

\begin{tabular}{|l|l|l|}
\hline S.No. & Scales & $\begin{array}{l}\text { Cronbach's Alpha } \\
\text { Reliability Coefficient }\end{array}$ \\
\hline 01 & Psychological Capital (Luthan, Youssef \&Avolio, 2007b) & .864 \\
\hline 02 & Organizational commitment (Allen \& Meyer, 1990) & .879 \\
\hline 03 & Organizational Citizenship Behavior scale (Podsakoff, 1990) & .819 \\
\hline
\end{tabular}

\section{Table 2: Reliability Alpha score}

The internal consistency of items was assessed by computing the total reliability of all the scale. The total reliability scale for the study is mentioned in Table 2, indicating an overall reliability factor as good for all the scales. This reliability value for study is substantial considering the fact that the highest reliability that can be obtained 1.0.

\section{Data Analysis Methods}

\section{Correlation Analysis}

Pearson correlation coefficientwas computed to find out the relationship between the variables:

${ }^{* *} p<0.05$

\begin{tabular}{|l|l|l|l|l|l|}
\hline & MEAN & S.D. & PC & OC & OCB \\
\hline PC & 156.35 & 5.51 & 1 & & \\
\hline OC & 52.64 & 8.98 & $.59^{* *}$ & 1 & \\
\hline OCB & 114.56 & 18.91 & $.72^{* *}$ & $.64^{* *}$ & 1 \\
\hline
\end{tabular}

It can be observed that there is significant relationship between Psychological Capital perceptions and Organizational commitment as $r=0.59$ and hence Hypothesis 1 has been accepted at 0.05 level of significance. Moreover Psychological Capital perceptions is also significantly correlated with Organizational Citizenship Behavior $(\mathrm{r}=0.72)$ and Organizational Commitment is also significantly correlated with Organizational Citizenship Behavior ( $r=0.64)$, thus Hypothesis 2 is accepted. 


\section{Psychological Capital as Predictor of Organizational Commitment and Organizational Citizenship Behavior}

\section{Regression Analysis}

Regression analysis is being done to find the relationship between certain dimensions and variables. Linear regression attempts to model the relationship between two variables by fitting a linear equation to observed data. One variable is considered to be an explanatory variable, and the other is considered to be a dependent variable. Psychological Capital is taken as the independent variables while all other variables:Organizational Commitment andOrganizational Citizenship Behavior are takenas the dependent variable. Stepwise Regression analysis has been done on the variables.

\begin{tabular}{|l|l|l|l|l|l|l|}
\hline Variables & $\mathrm{R}$ & $\mathrm{R}^{2}$ & Adj R $^{2}$ & S.E. of Estimate & F-value & Sig \\
\hline $\begin{array}{l}\text { ORGANIZATIONAL } \\
\text { COMMITMENT } \\
\text { Psychological Capital }\end{array}$ & .59 & .35 & .031 & 5.42929 & 7.905 & .005 \\
\hline $\begin{array}{l}\text { ORGANIZATIONAL } \\
\text { CITIZENSHIP BEHAVIOR } \\
\text { Psychological Capital }\end{array}$ & .72 & .84 & .080 & 18.13910 & 19.852 & .000 \\
\hline
\end{tabular}

Table 4: Stepwise Multiple Regression Analysis

Table 4 represents Stepwise Multiple Regression Analysis to predict values of Organizational Commitment and Organizational Citizenship Behavior using Psychological Capital as Independent Variable. Organizational Commitment has been predicted by Psychological Capital where $\mathrm{R}=.59, \mathrm{R}^{2}=.35$ and $\mathrm{F}=7.905$. 35\% variance in Organizational Commitment is being caused by Psychological Capital. Thus Hypothesis 3 is accepted.

Organizational Citizenship Behavior has been predicted by Psychological Capital where $\mathrm{R}=.72$, $\mathrm{R}^{2}=.84$ and $\mathrm{F}=19.852 .84 \%$ variance in Organizational Citizenship Behavior is being caused by Psychological Capital. Hypothesis 4 is accepted.

\section{CONCLUSION}

The need for the study was particularly because the existing literature on the relationship between Psychological Capital and work outcomes, has not fully explained the possible causes for the influence of Psychological Capital on work outcomes. Positive organizational behavior and psychological capital have implications for many personal and organizational related constructs but not many Indian studies could be found on this. It further explains that if organizations seriously promote positive organizational culture, it will help in developing psychological capital in the organizations which would ultimately help the organizational bottom line. The results of the present study also revealed that Psychological Capital is related to many other personal and organizational outcomes, it is imperative for the organizations to invest in developing psychological capital to really harness its benefits both for the employees and also for 


\section{Psychological Capital as Predictor of Organizational Commitment and Organizational Citizenship Behavior}

itself. The present research revealed that psychological capital in order to have positive work outcomes.

\section{LIMITATIONS}

This study is limited by the sample characteristics as it was conducted amongst limited teachers of public and private schools. The participants were predominantly female. It is not known whether the results would be applicable to other contextual settings or organizations. Generalizability of the present findings should therefore be examined in future research for other types of organizations, for mixed gender, and for more heterogeneous samples.

\section{REFERENCES}

Adams, J. Stacey (1963). Toward an understanding of inequity. Journal of Abnormal and Social Psychology,67, 422-436.

Adams, J. S. (1965). Inequity in Social Exchange. In L. Berkowitz (Ed.), Advances in experimental social psychology, 2, 267-299.

Bies, R. J., \&Moag, J. (1986). Interactional justice: Communication criteria of fairness. In R. J. Lewicki, B. H. Sheppard, \& M. Bazerman (Eds.), Research on negotiation in organizations,1, 43-55. Greenwich, CT: JAI Press.

Barnard, C.I. (1938). The Functions of the Executive. Cambridge, MassHarvard University Press. Bateman, T.S. \& Organ, D.W. (1983). Job satisfaction and the good soldier: the relationship between affect and citizenship. Academy of Management Journal, 26, 587-595.

Cohen-Charash, Y., \& Spector, P. E. (2001). The role of justice in organizations: A metaanalysis. Organizational Behavior and Human Decision Processes, 86,278-321.

Cropanzano, R.., Prehar, C. A., \& Chen, P. Y. (2002). Using social exchange theory to distinguish procedural from interactional justice. Group and Organizational Management, 27, 324-351.

Cropanzano, R., Rupp, D. E., Mohler, C. J., \&Schminke, M. (2001). Three roads to organizational justice. In J. Ferris (Ed.), Research in personnel and human resources management, 20, 1-113. Greenwich, CT: JAIPress.

Cohen-Charash, Y., \& Spector, P. E. (2001). The role of justice in organizations: A metaanalysis. Organizational Behavior and Human Decision Processes, 86, 278-321.

Diener, E., Tay, L., \&Oishi, S. (2013). Rising income and the subjective well-being of nations. Journal of Personality and Social Psychology, 104, 267-276.

Deutsch M. 1975. Equity, equality and need: what determines which value will be used as the basis for distributivejustice? Journal of Social Issues ,31,137-149.

Deci, E. L., \& Ryan, R. M. (1985). Intrinsic motivation and self-determination in human behavior. New York: Plenum 


\section{Psychological Capital as Predictor of Organizational Commitment and Organizational Citizenship Behavior}

Fatimah, O., Amiraa, A. M. \& Halim, F. W. (2011). The relationships between organizational justice, organizational citizenship behavior and job satisfaction, Pertanika J. Social Science \& Humanity, 19, 115 - 121.

Folger, R. (1977). Distributive and procedural justice: Combined impact of "voice" and improvement on experienced inequity. Journal of Personality and Social Psychology, 35,108-119.

Greenberg, J. (1987). Taxonomy of organizational justice theories. Academy of Management Review, 12, 9-22.

Gilliland, S. W., \& Hale, J. (2005). How do theories of organizational justice inform just employee selection practices? In J. Greenberg \& J. A. Colquitt (Eds.), Handbook of organizational justice: Fundamental questions about justice in the workplace, 411-438. Mahwah, NJ:Erlbaum.

Huseman, R., Hatfield, J., \& Miles, E. (1987). A new perspective on equity theory: The equity sensitivity construct. The Academy of Management Review, 12, 222-234.

Leventhal, G. S. (1980). What should be done with equity theory? New approaches to the study of fairness in social relationships. In K. Gergen, M. Greenberg, \& R. Willis (Eds.), Social exchange: Advances in theory and research, 27-55. New York: Plenum.

Leventhal, G. S. (1976). The distribution of rewards and resources in groups and organizations. In L. Berkowitz \& W. Walster (Eds.), Advances in experimental social psychology, 9, 91131. New York: Academic Press.

Katz, D. \& Kahn, R. (1966). Social Psychology of Organizations. New York, NY: Wiley.

Konovsky, M. A., \& Pugh, S. D. (1994). Citizenship behavior and social exchange. Academy of Management Journal, 37, 656-669.

Moorman, R. H., \& Blakely, G. L. (1995). Individualism-Collectivism as an individual difference predictor of organizational citizenship behavior. Journal of Organizational Behavior, 16, 127-142.

Moorman, R. H. (1991). Relationship between organizational justice and organizational citizenship behaviors: Do fairness perceptions influence employee citizenship? Journal of Applied Psychology,76, 845-855.

Niehoff, B. P., \& Moorman, R. H. (1993). Justice as a mediator of the relationship between methods of monitoring and organizational citizenship behavior. Academy of Management Journal, 36, 527-556.

Netemeyer, R. G., Bowles, J. S., MacKee, D. O., \&McMurrian, R. (1997). An investigation into the antecedents of organizational citizenship behaviors in a personal selling context. Journal of Marketing, 61, 85-98.

Organ, D.W., 1988. Organizational Citizenship Behavior: The Good Soldier Syndrome. Lexington Books. Lexington, MA.

Ryf , C. D. (1989a). Happiness is everything, or is it? Explorations on the meaning of psychological well-being. Journal of Personality and Social Psychology, 57(6), 10691081. 


\section{Psychological Capital as Predictor of Organizational Commitment and Organizational Citizenship Behavior}

Ryf , C. D. (1989b). In the eye of the beholder: Views of psychological well-being among middle-aged and older adults. Psychology and Aging, 4(2), 195-210.

Skitka, L. J., Winquist, J., \& Hutchinson, S. (2003). Are outcome justice and outcome favorability distinguishable psychological constructs? A meta-analytic review. Social Justice Research, 16, 309-341.

Tyler, T. R., \&Blader, S. L. (2000). Cooperation in groups: Procedural justice, social identity, and behavioral engagement. Philadelphia,Psychology Press.

Tang, T. L. P., \&Sarsfield-Baldwin, L. J. (1996). Distributive and procedural justice as related to satisfaction and commitment. S.A.M Advanced Management Journal, 2, 25-31.

Taylor, M. S., Tracy, K. B., Renard, M. K., Harrison, J. K., \& Carroll, S. J. (1995). Due process in performance appraisal: a quasi-experiment in procedural justice. Administrative Science Quarterly, 40, 495 - 523 